\title{
Down's Syndrome in Kuwait: Recurrent Familial Trisomy 21 in Sibs
}

\author{
S.A. Al-Awadi K.K. Naguib L. Bastaki S. Gouda \\ F.M. Mohammed S.J. Abulhasan W.A. Al-Ateeqi \\ D.S. Krishna Murthy
}

Kuwait Medical Genetic Centre, Maternity Hospital, Kuwait

\section{Key Words}

Down's syndrome $\cdot$ Non-disjunction

mosaicism · Consanguinity · Trisomy 21

\begin{abstract}
Objective: To study the families with recurrent trisomy 21 in sibs, and to understand the increased risk of recurrence in some selected families. The importance of parental mosaicism as a cause for non-disjunction or the possibility of genetic predisposition to nondisjunction is addressed. Methods: Three young unrelated Kuwaiti families each confirmed to have 3 sibs with regular trisomy 21 were investigated. Detailed chromosome analysis of the peripheral blood culture in Down's syndrome children and their parents was carried out. At least 100 cells in each of the cases were scored to exclude low grade mosaicism. Results: Regular trisomy 21 was confirmed in all the sibs in the three families. Mosaicism was not detected in parents. However, gonadal tissue mosaicism could
\end{abstract}

\begin{tabular}{ll}
\hline KARGER & (1) 1999 S. Karger AG, Basel \\
1011-7571/99/0082-0156\$17.50/0 \\
$\begin{array}{l}\text { Fax +4161306 1234 } \\
\text { E-Mail karger@karger.ch } \\
\text { www.karger.com }\end{array}$ & $\begin{array}{l}\text { Accessible online at: } \\
\text { http://BioMedNet.com/karger }\end{array}$
\end{tabular}

not be excluded, as it is not practical to study the gonadal biopsy in the parents. Conclusion: Though parental mosaicism (gonadal, more often maternal), has been reported in familial recurrent trisomy 21 cases, no mosaicism could be confirmed in our study. Our finding suggests that the possibility of a genetic predisposition to non-disjunction parental mosaicism should be considered in counselling families having sibs with trisomy 21.

\section{Introduction}

Trisomy 21 is the most common aneuploidy occurring as a sporadic event with a frequency of 1 in 600-800 live births [1, 2]. Down's syndrome due to primary trisomy 21 in 2 or more sibs of healthy, normal young parents ( $<30$ years) occurs rarely. Although the recurrence of trisomy 21 is $1-2 \%$ for young mothers after the first case $[3,4]$, there 
Table 1. The characteristic features of the three families with recurrent trisomy 21

\begin{tabular}{|c|c|c|c|c|c|c|c|c|c|}
\hline & \multicolumn{3}{|l|}{ Family I } & \multicolumn{3}{|l|}{ Family II } & \multicolumn{3}{|c|}{ Family III } \\
\hline & 1 & 2 & 3 & 1 & 2 & 3 & 1 & 2 & 3 \\
\hline $\begin{array}{l}\text { Age of child } \\
\text { years }\end{array}$ & 13 & 10 & $\begin{array}{l}\text { induced } \\
\text { abortion }\end{array}$ & 17 & 14 & 10 & 10 & 9 & $4 / 12$ \\
\hline Sex & female & female & female & male & male & male & male & male & male \\
\hline Nationality & Kuwaiti & Kuwaiti & Kuwaiti & $\begin{array}{l}\text { non- } \\
\text { Kuwaiti }\end{array}$ & $\begin{array}{l}\text { non- } \\
\text { Kuwaiti }\end{array}$ & $\begin{array}{l}\text { non- } \\
\text { Kuwaiti }\end{array}$ & Kuwaiti & Kuwaiti & Kuwaiti \\
\hline Maternal age & 25 & 28 & 33 & 33 & 36 & 40 & 22 & 23 & 32 \\
\hline Paternal age & 30 & 33 & 38 & 33 & 36 & 40 & 29 & 30 & 39 \\
\hline Consanguinity & \multicolumn{3}{|c|}{ less than second cousin } & \multicolumn{3}{|c|}{ second cousin } & \multicolumn{3}{|c|}{ non-consanguinity } \\
\hline Birth order & 3 & 4 & 6 & 4 & 5 & 7 & 2 & 3 & 4 \\
\hline Presentation & cephalic & cephalic & - & cephalic & cephalic & cephalic & cephalic & cephalic & cephalic \\
\hline Gestation & term & term & 13 weeks & term & term & term & term & term & term \\
\hline $\begin{array}{l}\text { Mode of } \\
\text { delivery }\end{array}$ & $\begin{array}{l}\text { sponta- } \\
\text { neous }\end{array}$ & $\begin{array}{l}\text { sponta- } \\
\text { neous }\end{array}$ & - & $\begin{array}{l}\text { sponta- } \\
\text { neous }\end{array}$ & $\begin{array}{l}\text { sponta- } \\
\text { neous }\end{array}$ & $\begin{array}{l}\text { sponta- } \\
\text { neous }\end{array}$ & $\begin{array}{l}\text { sponta- } \\
\text { neous }\end{array}$ & $\begin{array}{l}\text { sponta- } \\
\text { neous }\end{array}$ & $\begin{array}{l}\text { sponta- } \\
\text { neous }\end{array}$ \\
\hline $\begin{array}{l}\text { Patient } \\
\text { karyotyping }\end{array}$ & $\begin{array}{l}47, \mathrm{XX} \\
+21\end{array}$ & $\begin{array}{l}47, \mathrm{XX}, \\
+21, \\
16 \mathrm{qh}+\end{array}$ & $\begin{array}{l}47, \mathrm{XX}, \\
+21\end{array}$ & $\begin{array}{l}47, X Y \\
+21\end{array}$ & $\begin{array}{l}48, X X Y, \\
+21\end{array}$ & $\begin{array}{l}47, X Y \\
+21\end{array}$ & $\begin{array}{l}47, X Y, \\
+21\end{array}$ & $\begin{array}{l}47, X Y, \\
+21\end{array}$ & $\begin{array}{l}47, X Y, \\
+21\end{array}$ \\
\hline $\begin{array}{l}\text { Affected } \\
\text { relatives }\end{array}$ & & \multicolumn{2}{|l|}{2} & \multicolumn{3}{|c|}{0} & \multicolumn{3}{|c|}{0} \\
\hline $\begin{array}{l}\text { Maternal } \\
\text { karyotyping }\end{array}$ & \multicolumn{3}{|c|}{$46, X X$} & \multicolumn{3}{|c|}{$46, X X$} & \multicolumn{3}{|c|}{$46, X X$} \\
\hline $\begin{array}{l}\text { Paternal } \\
\text { karyotyping }\end{array}$ & \multicolumn{3}{|c|}{$\begin{array}{l}46, \mathrm{XY} \\
16 \mathrm{qh}+\end{array}$} & \multicolumn{3}{|c|}{$46, X Y$} & \multicolumn{3}{|c|}{$46, X Y$} \\
\hline $\begin{array}{l}\text { Satellite } \\
\text { association }\end{array}$ & \multicolumn{3}{|c|}{ high (55\%) } & \multicolumn{3}{|c|}{ not tested } & \multicolumn{3}{|c|}{ not tested } \\
\hline Tissue culture & \multicolumn{3}{|c|}{$\begin{array}{l}46, \mathrm{XY}, \\
16 \mathrm{qh}+\end{array}$} & \multicolumn{3}{|c|}{$46, X Y$} & \multicolumn{3}{|c|}{$46, X Y$} \\
\hline $\begin{array}{l}\text { Associated } \\
\text { anomalies }\end{array}$ & \multicolumn{3}{|c|}{-} & \multicolumn{3}{|c|}{-} & \multicolumn{3}{|c|}{ imperforated anus } \\
\hline
\end{tabular}

are no figures for the risk of multiple recurrence of trisomy 21 or other aneuploidy in young parents, but there are several reports suggesting that the probability is greater than expected. The aetiology of familial non-disjunction is not well established. There are several possible explanations for familial occurrence of aneuploidy. The first of these is of cryptic parental mosaicism [5-9]. The other possibility is 'genetic predisposition', as sug- gested by Alfi et al. [10] and others [11-13]. Whatever the cause, counselling young parents with 2 or more sibs with trisomy 21 poses difficulties.

We report here recurrent trisomy in three families, each of them having 3 sibs with primary trisomy 21 , and a brief review of families with 3 or more cases of trisomy 21 reported in the literature, speculating on its possible aetiology. 


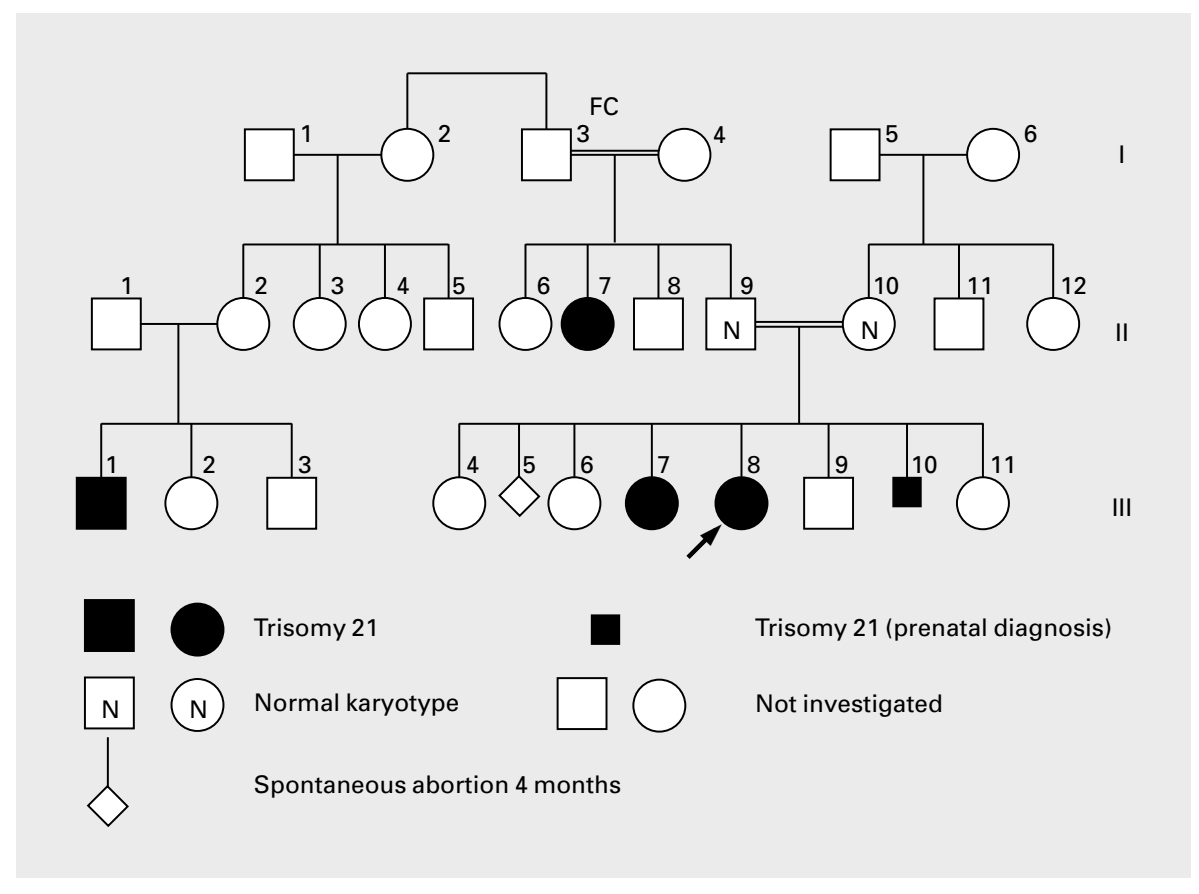

Fig. 1. Pedigree of family I with trisomy 21 in sibs and paternal aunt (II-7). Note consanguinity in parents and grandparents.

\section{Materials and Methods}

Three unrelated Kuwaiti families each with 3 Down's syndrome sibs were ascertained, clinically and cytogenetically. The clinical history of the three families is presented in table 1 and figures 1 and 2 .

\section{Family I}

The proband is a female infant, the product of the 4th pregnancy to consanguineous (less than first cousin) phenotypically normal parents. At birth, the parental ages were 23 and 28 years for the mother and father, respectively. Preconceptional and first trimester histories were unremarkable. At birth the baby showed the clinical stigmata of Down's syndrome. Pedigree study revealed that the proband has 2 elder phenotypically normal female sibs, 2 younger phenotypically normal sibs (brother and sister; fig. 1), 1 elder female sib with Down's syndrome and 1 early spontaneous abortion. Four years later the proband's mother conceived and prenatal diagnosis using transabdominal microvillus sampling technique revealed a regular trisomy 21 fetus, subsequently terminated.

\section{Family II}

The proband is a non-Kuwaiti male neonate, the product of the 7 th pregnancy to his consanguineous (second cousin) phenotypically normal parents. At birth the parental age was 40 years for both parents. Preconceptional, first and second trimester histories were unremarkable. A healthy normal male child was delivered at term by vaginal delivery with an average birth weight. On examination at birth he showed the typical features of Down's syndrome. His 2 elder brothers showed clinical features of Down's syndrome with regular trisomy 21 cytogenetically. Interestingly, although 1 of the children had double aneuploidy $48, \mathrm{XXY},+21$, he presented with clinical features of Down's syndrome.

\section{Family III}

The proband, a Kuwaiti male neonate, the result of the 3rd pregnancy to his non-consanguineous phenotypically normal parents. At birth parental ages were 23 and 28 years for both his mother and father, respectively. Preconception, first and second trimester histories were unremarkable and the pregnancy ended at 


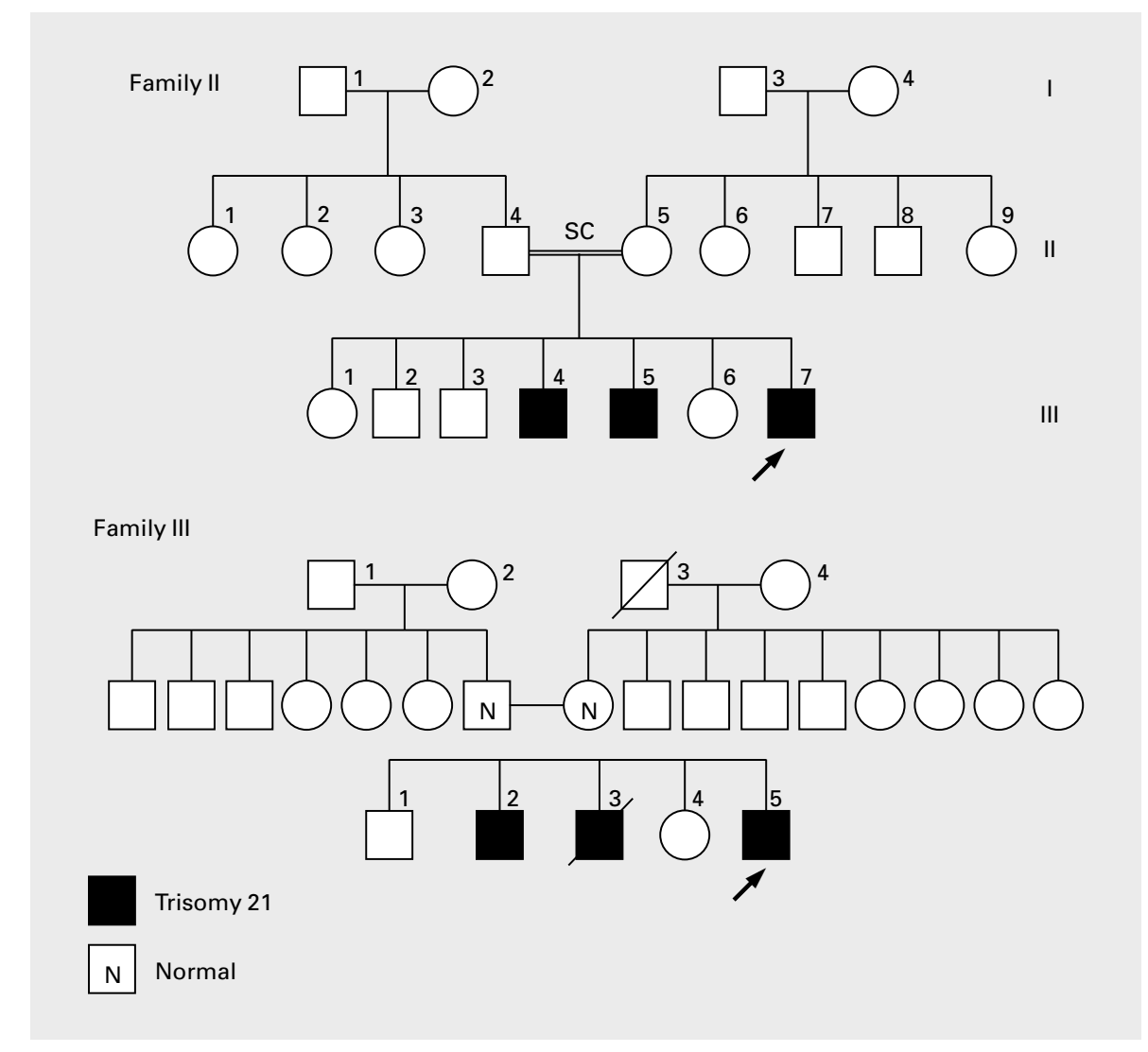

Fig. 2. Pedigree of families II and III showing trisomy 21 in 3 male sibs and parental consanguinity in family II.

term by spontaneous vaginal delivery. Pedigree study revealed that the proband had 2 elder male sibs, 1 of whom was similarly affected, and subsequently the proband's mother delivered a male child who also showed clinical features of Down's syndrome.

\section{Cytogenetic Studies}

Cytogenetic analysis in all the sibs and parents of the three families were carried out using peripheral blood lymphocyte culture and Giemsa trypsin banding technique. A minimum of 20 metaphases were scored and 3-5 cells were karyotyped in each case. In order to exclude mosaicism, 50-100 cells were scored. Mosaicism was not detected in the parents of the three families in the peripheral blood cultures. However, the possibility of tissue-specific mosaicism (gonadal) cannot be excluded.

Down's Syndrome in Kuwait

\section{Discussion}

The presence of 2 or more sibs affected with a chromosome abnormality may suggest the existence of a familial factor leading to an error in chromosome segregation in families having multiple members with aneuploidy [14-16], i.e., a genetic susceptibility to nondisjunction. Mosaicism in man may be under genetic control as has been shown in maize and drosophila. However, the presence of trisomy 21 in multiple sibs may be either due to mosaicism in one of the parents or an inherited predisposition [17]. The prevalence of

Med Principles Pract 1999;8:156-163 
Table 2. Recurrent trisomy 21 in sibs: summary of reported cases

\begin{tabular}{|c|c|c|c|c|c|c|}
\hline \multirow{2}{*}{$\begin{array}{l}\text { Family } \\
\text { No. }\end{array}$} & \multirow{2}{*}{$\begin{array}{l}\text { Sibs with } \\
\text { trisomy } 21\end{array}$} & \multicolumn{2}{|l|}{ Parental age } & \multicolumn{2}{|c|}{ Mosaicism } & \multirow[t]{2}{*}{ Reference } \\
\hline & & maternal & paternal & maternal & paternal & \\
\hline 1 & 3 & $25,28,29$ & - & + & - & Weinstein and Warkany [26] \\
\hline 2 & $3^{\mathrm{a}}$ & $30-32$ & $29-31$ & - & - & Dallaire and Fraser [27] \\
\hline 3 & 3 & $19-32$ & - & + & - & Aarskog [28] \\
\hline 4 & 3 & $22-24$ & - & + & - & Nuzzo et al. [29] \\
\hline 5 & 3 & & - & + & - & Begleitter et al. [30] \\
\hline 6 & 3 & $24,27,29$ & - & + & - & Osuna and Moreno [31] \\
\hline 7 & 4 & $17,19,21,25$ & $36,38,39$ & - & - & Frohlich et al. [32] \\
\hline 8 & 3 & $25,28,29$ & - & + & - & Harries et al. [5] \\
\hline 9 & 3 & & - & + & - & Maximillian et al. [33] \\
\hline 10 & 3 & $27,29,31$ & $29,32,33$ & + & - & Uchida and Freeman [34] \\
\hline 11 & 3 & $25,26,34$ & - & - & - & Cavalli et al. [35] \\
\hline 12 & 6 & $23-30$ & $26-33$ & + & - & Nielsen et al. [36] \\
\hline 13 & 4 & - & - & + & - & Sachs et al. [8] \\
\hline 14 & 3 & $24,29,35$ & $25,30,36$ & - & - & Pangalos et al. [37] \\
\hline 15 & 3 & $<30$ & - & - & - & Therman and Susman [38] \\
\hline 16 & 3 & $22,23,27$ & $39,40,44$ & + & - & Tseng et al. [39] \\
\hline 17 & 3 & $19,25,29$ & - & - & - & Quaife and Al-Gazali [40] \\
\hline 18 & 3 & $18,19,26$ & 22,2330 & + & - & Krishna Murthy and Farag [41] \\
\hline 19 & 3 & $31,33,34$ & $36,38,39$ & - & - & Krishna Murthy and Farag [41] \\
\hline 20 & 3 & $21-43$ & $32-49$ & - & - & Petersen [42] \\
\hline 24 & 7 & $<35$ & $<35$ & + & - & Ives et al. [43] \\
\hline 21 & 3 & $25,28,33$ & $30,33,38$ & - & - & present study \\
\hline 22 & 3 & $33,36,40$ & $33,36,40$ & - & - & present study \\
\hline 23 & 3 & $22,23,32$ & $29,30,39$ & - & - & present study \\
\hline
\end{tabular}

Mosaicism: $+=$ present $;-=$ absent.

a This family was reinvestigated by Uchida and Freeman [34]. Maternal mosaicism was confirmed in $2 \%$ of the cells. Mosaicism: $47, \mathrm{XX},+21$ in ovarian tissue $(100 \%)$.

chromosome 21 mosaicism in a random normal population is not known in most newborn surveys because large numbers of cells are not scored to exclude low grade mosaicism. Very few authors agree with the existence of a single-gene hypothesis $[10,18,19]$. However, other authors reported no evidence to support the suggestion of an inbreeding effect [12, 2025]. In the literature very few reports describe Down's syndrome in sibs (table 2), but some authors found maternal mosaicism as the underlying cause for recurrent Down's syndrome [29, 31, 44]. On the other hand,
Bartsch et al. [45] described a Spanish family who had 2 sibs with dup (21q) Down's syndrome whose mother has three different chromosome anomalies: a chromosome 22 with an unusual pericentromeric region that contains alphoid DNA from chromosome 21/13 and chromosome 22, an isochromosome $21 \mathrm{p}$, and an isochromosome 21q in a rare second cell line.

In the present study, we report three families with 3 sibs having regular trisomy 21 , in addition to nine other families who had 2 sibs with regular trisomy 21 Down's syndrome 
who were recorded among the 1,650 families with 1 Down's syndrome registered in Kuwait making a prevalence rate of 7.3/1,000 Down's patients. This recurrent rate of familial Down's syndrome is higher than the expected prevalence in a highly inbred population like Kuwaitis where the incidence of consanguinity is estimated to be $54.3 \%$ [46]. However, this rate does fit with the high incidence rate of Down's syndrome registered in Kuwait where the incidence rate was estimated to be 4/1,000 live births [unpublished data]. This finding necessitates the need to correct the figures of estimated recurrence risk after the 1st Down's syndrome patient in the general $\mathrm{Ku}-$ waiti population from $2.6 / 1,000$ to $8 / 1,000$ births. This new estimate is based on the new incidence figure of Down's syndrome registered in Kuwait. After the 2nd Down's syndrome child the estimated recurrence risk will be as high as $30 \%$.

Cytogenetically, neither mosaicism nor cytogenetic abnormality were found in any of the parents. Mosaicism cannot be excluded completely, particularly in the gonadal tissues of the parents. Accordingly, if we refer to the assumed genetic factor and consider it as a single recessive gene, one would expect multiplex families to be more prevalent especially in a highly inbred population like the Kuwaiti population. A similar finding was concluded by Basaran et al. [23]. The authors recorded 20 cases of Down's syndrome in sibs out of a population of 1,598 making a prevalence rate of 12.5/1,000 Down's patients. These findings together with our findings do not support the contribution of an autosomal recessive gene to the aetiology of non-disjunction, especially in highly inbred populations. Such a mechanism has not been assumed for other trisomies and it is unlikely that aneuploidy genes would preferentially affect chromosome 21 .

Non-disjunction could possibly be attributed to genetic, environmental or a combina- tion of the two factors. Theoretically genes predisposing to increased non-disjunction can be classified in several different ways: (a) gene(s) resulting in non-disjunction of a specific chromosome (e.g. chromosome 21)homoaneuploidy, (b) gene(s) that can predispose non-disjunction of different autosome/ sex chromosome in the same individual, or in sibs, due to parental and/or postzygotic nondisjunction-heteroaneuploidy (e.g. 48,XX, or XY,+21,+18; 48,XXY,+21 46,X,-X,+21). The occurrence of 'heteroaneuploidy' would not prove the existence of predisposition gene(s). Such outcome may be carried by parental mosaicism which has been demonstrated in some families with $>2$ trisomy 21 sibs. Familial 'heteroaneuploidy' is very rare. However, the occurrence of aneuploidy for different chromosomes is a better evidence for genetic predisposition although environmental factors could also be invoked as a possible cause. Amniocentesis and live birth data provided little evidence for a strong 'heteroaneuploidy effect' although a weak effect cannot be excluded. Studies in abortions are suggestive of genetic mosaicism of heteroaneuploidy [25].

In conclusion, non-disjunction could be possibly attributed to genetic, environmental or combined factors. Unfortunately, the nature of the mechanism of the genetic factor is yet to be revealed. The single-gene hypothesis is not yet accepted and even if accepted it must be limited to very specific situations. A hidden low grade mosaicism in one of the parents' blood or gonadal mosaicism may be the underlying cause and is not absolutely excluded in this report. Further investigations for all families including cytogenetic, FISH and DNA studies are highly recommended and will be arranged in the near future. The present report strongly supports that a subgroup of Down's syndrome families are at increased risk of recurrence. 


\section{References}

1 McKusick VA: Mendelian Inheritance in Man: A Catalogue of Human Genetics and Genetic Disorders, ed 11. Baltimore, Johns Hopkins University Press, 1994, vol II, MIM-158250; MIM-190685; MIM257300.

2 Hook E, Cross P, Schrenemacheis D: Chromosomal abnormalities at amniocentesis and in liveborn infants. JAMA 1983;249:2034-2038.

3 Mikkelsen M: Down syndrome. Hum Genet 1971;121:1-28.

4 Mikkelsen M, Stene J: Previous child with Down syndrome and other chromosome aberration: Group report; in Murken JD, Stengel-Rukowski S, Schwinger E: Prenatal Diagnosis of Genetic Disorders. Stuttgart, Enke, 1989, pp 22-29.

5 Harries D, Beyleiter M, Chamberlin J, Hankins L, Mogenis R: Parental trisomy 21 mosaicism. Am J Hum Genet 1982;34:125-133.

6 Parke J, Gross F, Pixley R, Deal J Trisomy 21 mosaicism in two successive generations in a family. $\mathrm{J}$ Med Genet 1980;17:48-49.

7 Richards B: Investigation of 142 mosaic mongols and mosaic parents of mongols: Cytogenetic analysis and maternal age at birth. J Ment Defic Res 1974;18:199-208.

8 Sachs E, Joshoda M, Los F, Pijpien $\mathrm{H}$, Wladmiroff J: Trisomy 21 mosaicism in the gonads with unexpected high recurrence risk. Am J Med Genet Suppl 1990;7:186-188.

9 Tuck C, Bennet J, Vamla M: Down's syndrome and familia aneuploidy; in Berg JM (ed): Perspectives and Progress in Mentally Retarded, ed 2. Baltimore, University Park Press, 1984, pp 167-180.

10 Alfi OS, Chang R, Azen SP: Evidence for genetic control of nondisjunction in man. Am J Hum Genet 1980;132:477-483.

11 Bell A, Gripps M: Familial aneuploidy: What risk to sib? Can J Genet Cytol 1974;16:113-119.

12 Kwiterovich P, Cross J, McKusick VA: Mongolism in an inbred population. Bull John Hopkins Hosp 1966;119:268-275.
13 Devoto M, Prosperi L, Bricarelli D, Coviello D, Croci G, Zelantel L, Ferranti G, Tenconi R, Stomeo C, Romeo G: Frequency of consanguineous marriages among parents and grand parents of Down syndrome patients. Hum Genet 1985;70:256-258.

14 Ford CE, Jones K, Miller O, Mittwoch U, Penrose L, Ridler M, Sapiro A: The chromosome in a patient showing both mongolism and Klinefelter's syndrome. Lancet 1959;i: 709

15 Lanman JL, Shlarin B, Cooper H, Hirschhorn K: Klinefelter's syndrome in a ten months old mongolism idiot. N Engl J Med 1960;263: 887.

16 Therman E, Patau K, Smith D, Demers R: D trisomy and XO gonadal dysgenesis in two sisters. Am J Hum Genet 1961;13:193-204.

17 Hamerton JL, Brigges S, Gianelli F, Carter C: Chromosomal studies in detection of parents with high risk of second child with Down's syndrome. Lancet 1961;ii:788.

18 Bakker B, Carpenter A, Esposito M, Esposito R, Sandler L: The genetic control of meiosis. Annu Rev Genet 1976;10:53-134.

19 Puri R, Khanna K, Bhargava I, Balakrishnan S: Role of consanguinity in chromosomal syndromes. Indian $\mathbf{J}$ Med Res 1977;65:859-864.

20 Matsunaga E: Down's syndrome and maternal inbreeding. Acta Genet Med Gamellol 1966;15:224-229.

21 Juberg R, Davis L: Aetiology of nondisjunction lack of evidence for genetic control; in McKusick VA (ed): Medical Genetics Studies of the Amish. Baltimore, Johns Hopkins University Press, 1978, pp 449458.

22 Naguib KK: Consanguinity and Chromosomal Aberrations; thesis Medical Research Institute, Alexandria University, 1984.

23 Basaran N, Cenani A, Sayh BS, Ozkinay C, Artan S, Seven H, Basaran A: Consanguineous marriages among parents of Down patients. Clin Genet 1992;42:13-15.

24 Naguib K, Al Awadi S, Moussa M, Mohammed F, Attia M: Down syndrome in sibs: A study of recessive hypothesis controlling nondisjunction. Bull HIP H 1992;22:125-133.
25 Hecht F, Brynat J, Gruber D, Townes P: The nonrandomness of chromosomal abnormalities: Association of trisomy 18 and Down's syndromes. N Engl J Med 1964;271: 1081-1086.

26 Weinstein ED, Warkany: Maternal mosaicism and Down syndrome. $\mathrm{J}$ Pediatr 1963;63:599-604.

27 Dallaire L, Fraser FC: Two unusual cases of familial mongolism. Can $\mathrm{J}$ Cytol 1965;4:540-547.

28 Aarskog AJ: Cited from Hamerton JL (ed): Human Cytogenetics. Academic Press, 1970.

29 Nuzzo F, Stefanini M, Simoni G, Larizza L, Mottura A, Reali E, Franceschini P: A family with three sibs carrying trisomy 21. Ann Génét 1975;18:111-116.

30 Begleitter et al: Cited from Frohlich et al. [32].

31 Osuna A, Moreno A: Regular G21 trisomy in 3 sibs from mother with trisomy 21 mosaicism. J Med Genet 1977;14:286-287.

32 Frohlich GS, Schdnhaut AG, Tortora JM: Trisomy 21 Down syndrome in sibship. N Y State J Med 1979;79: 929-930.

33 Maximillian C, Pop T, Duca D, Simionescu L, Danielescu M, Loan D: Familial Down syndrome. Endocrinologie 1981;19:65-68.

34 Uchida IA, Freeman VCP: Trisomy 21 Down syndrome paternal mosaicism. Hum Genet 1985;70:246248.

35 Cavalli J, Fontoura E Jr, Sbaluiero IJ: Letter to the Editor: Down syndrome owing to simple trisomy 21 in first cousins. Am J Med Genet 1985;22:831.

36 Nielsen KG, Poulsen H, Mikkelsen M, Stender E: Multiple recurrence of trisomy 21 Down syndrome. Hum Genet 1988;78:103-105.

37 Pangalos CG, Talbot CC Jr, Lewis JG, Adelsberger PA, Petersen MB, Serre JL, Rethore MO, et al: DNA polymorphism analysis in families with recurrence of free trisomy 21 . Am J Hum Genet 1992;51:10151027. 
38 Therman E, Susman M: Meiotic abnormalities; in Human Chromosome Structure, Behaviour and Effects, ed 3. Berlin, Springer Verlag, 1993, pp 190-202.

39 Tseng LH, Chuang SM, Lee TY, Kotm: Recurrent Down syndrome due to maternal ovarian trisomy 21 mosaicism. Arch Gynecol Obstet 1994;255:213-216.

40 Quaife R, Al-Gazali L: Trisomy 21 in sibs. Emirate Med J 1994;12: 150-153.

41 Krishna Murthy DS, Farag TI: Recurrent regular trisomy 21 in two Bedouin families: Parental mosaicism versus genetic predisposition. Ann Génét (Paris) 1995;38:217224.
42 Petersen MB: Origin and mechanism of chromosome aneuploidy in Down syndrome. Cytogenet Cell Genet Suppl 1997;77:1.

43 Ives EJ, Alderdice PW, Bridge PJ, Barret IJ, Kolousek DK, Conolly Wilson MJ, Crowley MR: A mosaic trisomy 21 woman with seven trisomy and cytogenetically normal pregnancies. Am J Hum Genet Suppl 1997;4:726,A-128.

44 Perroni L, Dagna Bricarelli F, Grasso M, Pierluigi M, Baldi M, Pedemonte C, Strigini P: Crossing over and chromosome 21 nondisjunction: A study of 60 families. Am J Med Genet 1990(Suppl 7):141-147.

45 Bartsch O, Konig U, Petersen M, Poulsen H, Mikkelsen M, Palau F, Prieto F, Schwinger E: Cytogenetic, FISH and DNA studies in 11 individuals from a family with two siblings with $\operatorname{dup}(21 \mathrm{q})$ Down syndrome. Hum Genet 1993;92:127132.

46 Al-Awadi S, Moussa M, Naguib K, Farag T, Teebi A, El-Khalifa M, ElDossary L: Consanguinity among the Kuwaiti population. Clin Genet 1985;27:483-486. 